\title{
Oratorical Style and Performance in the Epideictic Speeches of American Presidents
}

\begin{abstract}
Epideictic speeches have often tended to be overlooked in rhetorical studies as texts that are merely ornamental in nature and function; however, their apparent innocuousness may conceal a subtle, cumulative role in political persuasion and consensus-formation. This article discusses the rhetorical style of epideictic memorial speeches by American presidents. Drawing on rhetorical scholars from Aristotle to Jakobson and Burke, the author considers the poetic function of language. In epideixis, there is a strong rhetorical integration of text, audience, performance and environment. Even in prosaic political contexts, language can be deployed poetically, and linguistic choices by political speakers contribute to the evaluation by the audience of a speaker's charisma. Using memorial speeches as an example of literary/non-literary hybridity, the author observes that the key persuasive element in epideixis is its poetic predictability.
\end{abstract}

\section{Key words}

Memorial Day; Gettysburg; epideixis; rhetoric; stylistics; discourse; performance; poetic function; aesthetics; charisma

\section{Introduction}

The rhetorical term epideixis encompasses the type of public speaking found at ceremonial events, such as remembrance of those killed in war, where the attention of the audience (physically present or distant, e.g. on TV) is focused primarily on the ornamental, affective and aesthetic content of the speaker's entire performance. This paper draws on a corpus of 27 texts (approximately 26,000 words and 8 different presidents), to discuss the rhetorical style of American Memorial 
Day speeches ${ }^{1}$ from 1966 to 2009 , and also their stylistic prototype, Lincoln's (1863) Gettysburg address. ${ }^{2}$ The underlying purpose of an earlier study from which this paper is derived (Slavíčková 2013) was to highlight the relationship between the rhetoric of American war commemoration and the crystallization of ideological values favourable to war (as opposed to diplomacy). The earlier study treated Memorial Day as a genre, rather than emphasizing distinctions between different presidential styles. My principal focus here is to use Memorial Day as a diachronic case study for advocating the analysis of commemorative presidential speeches as a distinct performance in the rhetorical repertoire, based on an overview of relevant approaches; and, further, to discuss the aesthetic, stylistic qualities of political discourse and other persuasive non-literary genres in general.

The American Memorial Day state holiday takes place at the end of May, and has its historical origins in the Civil War (1861-1865). In 1966, President Johnson initiated the tradition of the presidential address, typically made at Arlington Cemetery in Virginia, where many war dead are interred, and most subsequent presidents have made the address in every year of their incumbency. Taken together, the content and narrative structure of the speeches are somewhat uniform and predictable, characterized by, among other things, use of archaic and/or euphemistic language (e.g. in this place where valour sleeps... (Bush Jr. 2006)), referencing of pivotal moments and heroes in US history, legitimization of past, present and future wars, and the invocation of shared cultural practices and values.

Epideixis can be studied within a discursive framework of persuasion, i.e. the activation of individual motivations that become transformed into more stereotyped and socially grounded behaviours. Though hard to measure, relationships of language style and cognition are significant enough to be of interest to discourse analysts like myself; the persuasion process is not simply the consequence of a series of strategic behaviours by persuaders, or rational calculations by persuadees. War commemoration rituals may have a political significance in terms of building consensus in societies. In more sceptical terms, the mass "healing" function of a memorial event channels raw (and politically "dangerous") emotional power engendered by personal bereavement (the loss of a loved one), returning it to a more synthesized, socialized, managed, "public" response.

\section{Classical epideixis}

The classical Greek rhetorical scholars had little concern for setting distinctions between poetry and referential prose as mutually exclusive modes of expression. Aristotle and Isocrates both highlight the importance in persuasion of rhythm, metre and other forms; later, however, as the bifurcation of literature and nonliterature entrenched itself in academe, these stylistic features began to be associated only with literature. The three principal modes of persuasion, according to Aristotle, are logos (the use of rational argument but also encompassing logical fallacy and heuristic such as topos, or commonplace argumentation); pathos (ap- 
peal to the emotions, engendering mass anger, joy, etc.); and ethos (the invocation of personal credibility, charisma or status and the activation of positive association). Aristotle also identifies three types, or genera, of oratory, which determine the style of delivery. The deliberative genre (genus deliberativum) pertains to declarations of future policy and action, is focused on the specific issue under debate, and is strongly persuasion-oriented. The forensic genre (genus iudiciale) deals with investigation of past action, especially with regard to judicial accusation and defence. The third, perhaps most nebulous and certainly the most analytically neglected of the three is the epideictic genre (genus demonstrativum).

Epideixis encompasses funeral eulogies and memorial speeches, and, in Aristotle's view, expresses the attribution of honour, praise (or blame) to an action or actor, who may be absent or dead. It also expresses the older "display" function of rhetoric, and can therefore be discerned also in non-verbal aesthetic expression such as fine art and architecture. ${ }^{3}$ In its broadest modern sense, I would argue that epideixis also encompasses the highly televisual self-display and narcissism of the modern celebrity whose performance is determined by the audience. Traditionally, epideictic oratory is expressed via the symbolic practice of bearing witness to an event, whether or not audience or speaker are personally implicated. There is a hybridity about epideixis that can be seen to facilitate rhetorical sleight of hand: many commemorative and epideictic speeches made in the public domain are simultaneously deliberative, for example, in the sense that eulogies for the dead provide the opportunity, under the guise of bearing witness, for speakers to advance a particular political agenda.

The primary functional purpose of epideixis can be defined as that of arousing an emotional reaction in an audience via the use of poetic forms and ritualistic language, often in conjunction with other modes of expression such as visual display, music, or a chosen location. In other words, epideixis is focused on activating sensory arousal through aesthetic experience rather than rational verbal processing.

In classical rhetoric, the audience has a role to play too as judges of the speaker's performance. Quintilian also refers to the connection between good oratory and perceptions of the speaker as morally good. Although pathos in the communion of speaker and mass audience may not always be easily determined, both the ritualized nature of most epideictic speech events, the presence of a mass audience, and the speaker's occupation of argumentational common ground are likely to circumscribe the potential for dissent. I would argue that ethos too has a key function in this genre, even though in the case of Memorial Day and Gettysburg, eloquence and leadership are presupposed, given the status of the presidential office.

Key to epideixis is what Perelman and Olbrechts-Tyteca (1969: 142) call presence. This they define as "certain elements on which the speaker wishes to centre attention in order that they may occupy the foreground of the hearer's consciousness"; presence is therefore about presentation, display, or the strategic, selective display that is representation (literally, re-presentation). Commemorative 
speeches have to resonate with the emotional, cultural and cognitive orientation of the listener; understanding the stylistic forms of rhetorical presence may also help in building an awareness of how charisma is constructed in the relationship between audience and speaker.

Though we may at first assume that commemorative speeches are concerned primarily with the past, on reflection the picture is more complex. Rhetorical scholars have long sought to pin down the precise qualities that render a text epideictic while simultaneously relevant to the more mundane deliberative practicalities of political communication. Focus on the pragmatically performative function of epideixis overemphasizes its ritualistic function at the expense of other important functions such as expediency and affect. Rhetorically, Lincoln's Gettysburg address, for example, (re)contextualizatizes past events (the war up until and including the battle) and present circumstances (the "moment" of the speech) for a future political objective (a vision of national unity). Both the significance of the epideictic genre in persuasion and attitude change, and its ethical status, appear to draw diverse reactions from rhetoricians. For instance, Chase (1961) dismisses epideixis as mere artfulness - style with no substance or basis in truth (Burgess 1902). Indeed, the epideictic genre may be notable for its tendency to hyperbole, and for constructing heroic subjects. Both the subtle trickery inherent in epideixis, and the classical focus on the argumentational brilliance of the individual narrator/actor confronted with a sceptical audience, were used to dramatic effect in the ironic funeral eulogy by Mark Anthony in Shakespeare's Julius Caesar.

In a study that attempts to redefine the importance of the epideictic in modern democratic societies (drawing on Jacques Derrida's eulogies), Rollins (2005) points out that the classical rhetoricians and their audiences tended to put a higher value on the deliberative and forensic genres, wherein the speaker's reputation is actually at stake. The epideictic genre meanwhile was relegated to the status of mere ornamentation, demanding little more than appreciation of the speaker's skill and showmanship, as well as some shared indulgence in matters of civic concern. Aristotelian rhetorical scholarship has, over centuries, generally paid far more attention to deliberative and forensic oration, presupposing that the epideictic genre has little or nothing to offer in terms of argumentation structures in the text, or critical thinking on the part of the audience, and that its contribution to driving social and political change has been minimal. Perelman and OlbrechtsTyteca (1969) seek to correct this misperception of the strategic significance of the epideictic genre and the tendency for scholars to undervalue it. Epideixis, they believe, has considerable potential for ideological reinforcement, at least in the longer term:

Epideictic oratory has significance and importance for argumentation because it strengthens the disposition towards action by increasing adherence to the values it lauds. 
Rollins agrees that this interpretation advances a more future-oriented (i.e. political, deliberative) understanding. Content and narrative structure, as with every other form of argumentation, are pragmatically shaped by the speaker's evaluation of the audience. We can thus conceptualize the genre as dynamic, albeit within ritualistic boundaries. Epideixis can be inextricably but implicitly linked with political action, and its apparent innocuousness (surrounded as it is by the usual visual, aural and emotional distractions of pomp and ceremony) may enable ideological messages to be readily concealed.

In an alternative perspective, Fisher and O'Leary (1996) propose the organic metaphor of Fisher (1970) that shifts the focus of categorization. According to this model, we can divide the functions of rhetorical discourse in terms of a speaker's motivation:

- to give life or acceptance to certain ideas (affirmation);

- to revitalize the life or acceptance of ideas (reaffirmation);

- to restore the health of ideas (purification);

- to undermine ideas (subversion);

- to undermine ideas and put into question any idea that insists things can be better (evisceration).

If we apply Fisher's functions to presidential commemorative speeches, we see the significance of reaffirmation. Indeed, Fisher himself works with the Gettysburg speech to demonstrate Lincoln's motivation. First, there is an immediate strategy to revitalize flagging morale in the midst of an extremely bloody war. However, and more importantly from a longer-term and more politically inflected point of view, there is a second motivation, to bring war's doubters back to the fold, and a third, to entrench the future unity of an American state with a centralized executive. Motivation is then exposed by consistencies in aspects of the speech as a performance, and here Fisher draws on the rhetorical philosopher Kenneth Burke (1945). Working with the underlying notion of "language as motives", Burke's dramatistic pentad enables us to anticipate the perceptual implications of emphasizing one of the following elements in in relation to the others, or their significance when considered alongside a range of plausible and interconnected alternatives:

- Act: What act has taken place?

- Agent: Who took action?

- Agency: How or with what?

- Scene: Where, when and in what context?

- Purpose: Why did they do it?

All aspects of the Gettysburg performance, including its location, audience and themes contribute to a reaffirming (to use Fisher's term) of the Civil War as legitimate, inevitable. With hindsight, they can further be seen as giving life to, 
i.e. affirming, the broader idea of war as an inevitable instrument of nation-building (the word nation occurs 5 times in this very short speech). The physical location of Lincoln's speech, on the battlefield of Gettysburg (scene), clearly affects and is affected by, the simplicity of its delivery and the high credibility of the deliverer (agent). We can add that this has even acquired further pathos over time, as the romantic fantasy of the modest Lincoln hastily scribbling his speech en route to Gettysburg has rooted itself in American cultural mythology. The textual theme of poetic rebirth and regeneration following death in battle (agency) enables Lincoln to reassure his audience of the event's historical value to future generations and set out discreetly his political vision of a unified, centralized system of political government (purpose).

The commemorative genre shows how focus on motive, furthermore, helps foreground the preference for ethos and establishing rapport through narrative, and the integrated nature of audience, actors and action. Burke's dramatistic framework, reworked for the social sciences by Goffman (1959) as a dramaturgical model focuses on individuals performing schematic scripts determined by context and tradition to fulfil particular roles in order to meet audience expectations in particular settings. Performing a role also enables or requires individuals to conceal their real opinions or emotions behind the mask or persona. Linguistic choices (e.g. the Memorial Day use of archaisms such as hallowed ground, where valour sleeps, fallen heroes, etc.) are "framed" by the demands of the actual situation, the established script for similar contexts (with Gettysburg and earlier Memorial Day speeches as prototypes), and the role the presidential actor is expected to play (as spokesperson for "nation").

\section{The poetic function in non-literary text}

[T] he linguistic study of the poetic function must overstep the limits of poetry, and, on the other hand, the linguistic scrutiny of poetry cannot limit itself to the poetic function.

(Roman Jakobson 1960)

My concern with the intersection of rhetoric and aesthetics necessitates some discussion of the cognitive implications of the poetic function. The innate creativity of humanity as a "symbol-using animal" is eloquently expressed by Burke (1966). The synchronic study of language within the structuralist tradition encompasses the manifestations of linguistic structures and their taxonomies at a particular moment in time. Jakobson's theories are also recognized as providing an additional important modification to linguistic theory, by taking an interest in the relationships between structures. In his theoretical representation of communication, Jakobson insists on a complex scheme, which incorporates the poetic in all forms of linguistic analysis, beyond the confines of literary prose and poetry. Poetic, in Jakobson's conceptualization, is any message which exists "for its own 
sake" (Jakobson 1960: 356); or, according to van Peer et al. (2007), the message "draw[s] attention to itself rather than, for instance, the context it refers to". Jakobson and other Prague Circle linguists were interested in the leakiness of the boundaries between the poetic and the prosaic, and the means by which addressees may be startled or amused by varying degrees of deviation from a linguistic norm. Jakobson's concept of markedness also accounts for the "psychological jolt", the unexpected aesthetic frisson, caused by grammatical, phonological or semantic signifiers, that motivates the listener to invest more effort in "elaboration". I believe that Jakobson's poetic function is therefore relevant to epideixis, a showy genre whose function is to intentionally draw attention to itself.

Aesthetic tropes are also significant. In an important contribution to semantics, Jakobson and Halle (1956) conceptualized a binary structure comprised of two axes, the axis of selection (vertical, metaphoric, symbolic) and the axis of combination (horizontal, metonymic, indexical). Discussion of the tensions between the two axes brings us into profoundly abstract and disputed territory, but it is worth outlining briefly the debates surrounding them, before discussing their implications.

The renaissance philosopher Giambattista Vico (1968) identified four rhetorical stylistic tropes: metaphor, metonymy, synecdoche and irony. These categories define the choices we have for representing knowledge, although language, as a signifying system, represents, rather than reflects, the world. Discussion of tropology was taken up in the 20th century by, among others, White (1978). Jakobson's reduction of tropes to a binary opposition of metonymy (incorporating synecdoche) and metaphor marks a key departure from what he sees as overpreoccupation with the metaphorical at the expense of the literal, which had hitherto sustained the bifurcation of literature and non-literature. The discussion is also supported by Foucault (1970), who argues further that identification of the dominant tropes in a culture is central to an "archaeological" understanding of epistemes - social rules, hierarchies, truths, and systems of belief in different historical periods. In this sense, both philosophers contributed greatly to the postmodern alignment of literary and social studies, and, in my view, to their mutual enrichment.

McQuarrie and Mick (1996) present a taxonomy of "artful deviation", rhetorical forms on a scale of deviation, with repetitive forms such as rhyme, anaphora and alliteration at its lower end, and more complex items such as metaphor and punning at the higher end. This arrangement also corresponds to the degree of cognitive effort expended by the reader to achieve understanding and the aesthetic pleasure that derives from satisfactory decoding. Their taxonomy also divides the forms into modes of figuration: tropes, but also schemes (derived from Leech's taxonomy of poetry, 1969) that correspond respectively to Saussurean (1977[1916]) paradigm and syntagm. In Saussurean terms, selection, or substitution (expressing meaning in one subject area using a signifier from another semantic domain), is structurally paradigmatic, involving choices of signifier from a possible range of viable, coherent signifiers. Regarding Memorial Day, we may 
for instance be interested in the implications of speaker preferences for, typically: anaphoric repetition/reformulation (e.g. Reagan, 1986, If we really care about peace, we must stay strong. If we really care about peace, we must, through our strength... We must be strong...); archaic, poetic nouns such as valour or hallowed ground; death euphemisms such as gave their lives or fell; temporal shifting (e.g. Fifty years ago...Today...); the synecdochic in-group (nation) we pronoun as opposed to $I$ as a president shifts focus from self as actor to nation as actor.

The poetic device of metaphor also plays a substituting role, positioning the signifier, and what is signified by it, as the central focus. The addressee may have to work hard at inferring the meaning of a metaphoric trope, since it may typically defy straightforward decoding, and be open to multiple levels of interpretation. McQuarrie and Mick argue (1996: 428) that as a poetic form, metaphor tends to be more deviant (or artful) than metonym (respectively stronger and weaker tropes); both are more deviant than rhyme or parison (both designated as schemes). The more deviant forms used, the more demanding the text will be to decode, with the danger that less motivated readers will disengage. "Plain speaking" critics of excessive artful deviation, may overlook metaphor's ubiquity in non-poetic language, even in scientific and factual discourses. Metaphor pervades prosaic speech, though it may go unnoticed (Lakoff and Johnson 1980; Kövecses 2002).

In a typical Memorial Day phrase, we ... have inherited a sacred burden, President Ford (1976) reworks a common metaphor: RESPONSIBILITY IS A HEAVY WEIGHT, to the extent that it hardly appears metaphoric at all. Similarly in speeches by other presidents, we see versions of HISTORY IS A JOURNEY (there is no going back, their sacrifice is paving the way to the future), or FREEDOM IS A LOCATION (living in freedom, building freedom, defend our freedom, stand guard on the frontiers of freedom) or FREEDOM IS A COMMODITY (the price our nation has paid for freedom, given their lives for freedom). Lakoff and Johnson (1980) argue that some novel metaphors become, over time, conventionalized and ultimately unremarked. Clearly, highly deviant metaphors (or reworkings) are less frequent in political discourse than in literature, though they are by no means rare, occurring with greater frequency in texts generated at key historical turning points, ${ }^{4}$ as rhetors seek to represent or reinvent new realities.

Metonymy (and its sub-category synecdoche, the representation of a part by a whole and vice versa) on the other hand, deals with the linking of one signified to another, where meaning emerges from the logical or experiential association between them. According to Wilden (1987), metonymy "consists in using for the name of a thing or a relationship an attribute, a suggested sense, or something closely related, such as effect for cause...the imputed relationship being that of contiguity" (Wilden 1987: 198). Meaning is engendered by the addressee by making connections between what is signified, and how, by association, other signifieds are created. Metonymic associations in the Memorial Day corpus may be straightforward (such as the common designation of an army with the synecdochic boots on the ground), but they may also be more abstract and open-ended, and difficult to distinguish from metaphor. When a Memorial Day speaker uses 
an abstract noun such as liberty, valour, tyranny or sacrifice, we see this may also be a metonymic "telescope"; our emotional response to it is shaped by the cognitive bundle of schematic associations we bring to it. Associations may be individualized by personal experience, but they are also highly socialized and historically determined.

Any sign (word, colour, sound, phoneme, etc.) forms the centre of a web of meanings, which intensify via articulation to other signs. Hence the frequency here of complex part-for-whole synecdoches, [t]his [Arlington] is sacred soil and the heart and the history of America (Clinton 2000) and their stories are the American story (Obama 2009). Clearly, in this case, the emotive power of a burial ground is connected to the associations made by its visitors, and this emotional experience can be channelled by the rituals during ceremonies performed, its visual and verbal aesthetic. The ritual power is achieved through intertextual connections - to past Memorial Days, to related speech acts such as funerals, eulogies and religious ceremonies. And just as, as Jakobson and Halle (1956) eloquently observe, the suicide of Anna Karenina is collapsed metonymically via Tolstoy's description of her handbag, I believe that a whole complex history of war death can be expressed by, inter alia, the small white headstones of Arlington. Each of them represents one fatality, but simultaneously in their uniformity, together they represent rhetorically and visually much more.

\section{Sound and signifcation}

In his discussion of the poetic function of language, Jakobson (1942) means any linguistic form that exists primarily as an expression of creativity with the function of being aesthetically satisfying to the addressee, and uses the example of the resonant political slogan I like Ike with its visual and phonological symmetry, to illustrate. He also points out that literary poetry by itself (though predominantly poetic, of course), like any verbal message, may perform numerous sub-functions, ranging from the relative referential third-person bias of epic poetry to the more emotive style of first-person narratives in lyric and romantic poems. Similarly, prose performs varied functions - with literary prose generally close to the poetic end of the spectrum and the computer manual, one assumes, at the referential extreme. This also has implications for the range of possible decodings (see Hall 1980). Some utterances (like memorial speeches) depend for their rhetorical effectiveness on their relative redundancy, achieved either through sound patterning or tropic familiarity, or both, and some forms may achieve more prominence in spoken delivery than in writing, or vice versa.

Jakobson does not suggest that isolated sounds and other signs are by and of themselves significant; rather, meaning emerges by metonymic contingency (linking) with other signs in the syntagmatic chain. Still, patterns show that selection cannot be entirely random. He points out that an individual phoneme such as / $\mathrm{p} /$ cannot signify, but there is a "scale of freedom" that magnifies signification 
as other phonemes are combined with it. The plosivity of $/ \mathrm{p} /$ becomes increasingly marked as it is used repetitively or combined with other plosives, for example in alliteration, or in opposition with contrasting sounds such as the softer fricatives $/ \mathrm{m} /$ or $/ \mathrm{s} /$.

Ivan Fonágy (1965) demonstrates the iconicity of sound, discussing the emotive function of interdependent phonetic articulations in poetry (including poetry in translation). Empirical study shows universality across cultural groups in perceptions of acoustic signs. The light and dark opposition features in linguistic analysis of particular phonemes, and vowel darkness relates to the degree of roundedness and fronting. Fonágy (1963) also identifies "aggressive" versus "tender", and even "manly" /r/ versus "feminine" /s/ consonants. His empirical research shows that audiences (including respondents with a sensory handicap such as deafness or blindness) tend to agree on the emotional inflection of a text separately from consideration of its semantic qualities.

Phonetic or structural deviation from an expected norm, for instance, the elongation of a vowel, or the selection of a word that is particularly consonant rich, or onomatopoeic, or gendered, does not simply carry a message - it is the message, if we accept that poetic meaning emerges out of contrast (linking what "is" against what "might have been"). Other stylistic sound variation that could influence "texture" can be discerned in non-semantic prosodic signs, such as vowel/ consonant positioning, phoneme length, elision, metre, and word and sentence stress, and paralinguistic signs such as nasalization and lisping. Emotional impact of a performance may be affected by physiological factors, such as the degree of muscular effort required to create sounds, and the relationship between phonemes and facial expression. These factors may contribute to the expression of an upbeat, aggressive or melancholic mood. Samuels (1972), observes the diachronic emergence, via Darwinian selection, of lexical groups whose phonological similarity reflects semantic unity, citing, for example, the negatively-inflected sneak, weak, bleak, freak. This indicates the relationship between phonemic choice (and thereby lexical choice) and affective meaning is more than merely arbitrary, even when socially-determined associations are factored out.

Empirical testing may well demonstrate that a prototypically solemn text such as a Memorial Day address contains a significant (higher than random) proportion of prosodic and phonemic features that are expressive of melancholy, including "dark" vowel preferences. We can consider whether the rather archaic noun tomb sounds more solemn than grave, or the verb yearn as opposed to long. However, this may be a case of the "phonaesthetic fallacy" (Simpson 2004) - interpreting phonemes as onomatopoeic signifiers in any text other than pure poetry, though Simpson concedes they may be a factor in "heightening" affective value. In my view, individual phonemes are unlikely to be strongly foregrounded in the genre of political oratory though it may happen with discernible preferences, e.g. for alliteration, archaism or anaphoric repetition. Anyway, I would argue that neither Memorial Day nor Gettysburg is uniformly melancholic; indeed, the commemorative genre demands an uplifting tone. 
The dominance of audio-visual media in the past half century has added considerably to the range of stylistic variables in political discourse. Audiences can now see and hear their political leaders in a wide range of environments. Observers have no doubt speculated on whether Lincoln's reedy speaking voice would today have required a "makeover". Sound is an important signifier in political communication, and it may be possible to identify evolving "phonologies of power", pertaining to marked regional/social styles, technological conditions, or paralinguistic idiosyncrasies, and their affective implications. Non-linguistic marked forms in oratory that may denote degrees of musicality, include greater range in pitch, tone, rhythm, volume, stress-timing, pace, etc. at the nonsegmental prosodic level. These operate in tandem with the linguistic forms such as lexical and grammatical choices that impact on commemorative narrative (e.g. tense-switching past to present to future), keyword repetition, intensifiers and metaphors, and the generation of crescendo and climax. Prosody is implicated in detection by hearers of affective inflection, though this is less likely to be needed when a message is unambiguous.

It is hardly surprising that political supporters will find a speaker's voice pleasing while opponents will find something to dislike. It would surely be more helpful, therefore, to say that politicians draw on an oratorical, dramaturgical repertoire that is determined by political and cultural tradition and the performative demands of the occasion (be it commemoration, a call to arms, a campaign for votes, a daytime TV show, etc.). Surely, when doing their job in their discursive domains, presidents actually sound rather similar.

\section{Style and charismatic performance}

Politicians want audiences to like and respect them, but determining whether a performance can be designated as charismatic is more complex. It is difficult to define political charisma, let alone seek to quantify it (but see attempts in the work of House and Shamir 1993; Fiol et al. 1999). It may be possible to claim that a charismatic leader engages directly with passion, with a disarming effect on audiences, rendering them less capable of reasoning. In American presidential politics, the pursuit of the charisma label is a professional sine qua non, accorded greater attention by media and historians (also when negatively deployed) than qualities such as executive efficiency or hard work.

Studies of leadership (encompassing entrepreneurial as well as political leadership) have also demonstrated the positive effects on audiences of evoking historical shared ground, collective experience, group inclusiveness, a coherent vision and traditional values. Fiol et al. (1999) also point out that sections of speeches (like memorial speeches) that express higher degrees of abstraction (such as nation, truth, justice, history, etc.) are more liable to confer Perelman and Olbrechts-Tyteca's (1969) "presence" and charisma than those dealing with more specific subjects, such as references to individuals, or a particular battle, or concrete 
policies such as taxation or health care. The commemorative genre itself has low referential specificity; references to individuals or locations (from the national canon of heroes and battles) are eponymous, abstract and metonymic in their reduction, as in Nixon's remark in 1973: The men and women who fell in America's wars, from Bunker Hill to Khe Sanh and Hue, have brought the promise of lasting peace on Earth closer for us all.

Emrich et al. (2001) conducted a detailed empirical study of linguistic choices (single words) and audience perceptions of presidential leadership and greatness, drawing on a wide range of earlier studies. They observe the rhetorical importance of overarching textual and discursive techniques such as storytelling, metaphor, rhyme, imagery and opaqueness in the establishment of a charismatic persona. The authors also reference earlier leadership studies that attempt to quantify greatness, and in their research seek to find connections between conceptualizations of political and literary greatness, citing, for instance, Colin Martindale (1975) who attempts description (using computer-based quantitative methods, but inspired by Freud, Jung and Fromm), of the criteria for long-term membership of the literary canon.

Martindale's innovative Freudian approach proposes two modes of thought. The primary mode is pure sensory response associated with the cognition processes of the child or when the subject is highly aroused, for instance, by drugs. The secondary mode is that of the rational, regulated world of the socially-functioning adult. Martindale observes that poetry readers displayed preferences for the first mode, i.e. subconsciously accessed, sensory, primordial image-based words (primary, pathos-oriented), as opposed to concrete concept-based words (secondary, logos-oriented). He also sought to map out the evolutionary process by which creative artists strive for originality within the ever-encroaching stylistic boundaries of literary genres, the inevitable, eternal search for novelty. Martindale concludes that the more vivid and visceral the imagery used by poets, the greater the likelihood that their work will be seen as boundary-shifting and the greater the likelihood of achieving long-term greatness.

Shifting the (artistic) sublime to the (political) banal, it is worth considering that just as with literary greatness, political greatness too seems predicated on meeting the challenge to create something new, and therefore memorable, from an ever-more limited range of linguistic and rhetorical possibilities. Emrich et al.'s study analyzed some of Martindale's semantic pairings in his Regressive Imagery Dictionary (which contrasts pairs of lexical choices) as they might relate to political rhetoric. These include, for instance, choices from the following synonymic pairs (image-based in the first position and concept-based in the second): sweat/work, root/source, frontier/limit, see/understand, as they were deployed in "pivotal" speeches. It seems, they propose, that political leaders are more likely to be perceived favourably when they appeal to pathos, via the poetic function, rather than appealing to logos. The research claimed a positive correlation between heavy use by US presidents of image-based, "poetic" words in public addresses and audience perceptions of their charisma and/or greatness. The persua- 
sive impact of such choices may also be reinforced by other signs that apparently activate subconscious desires. These may comprise, to take an example from conservative discourses, visual tropes like the "strict but loving patriarch" (e.g. portraits of stern leaders), and complex verbal choices (e.g. metaphors of moral accounting), as suggested by Lakoff (2004) that permeate presidential discourse (see also Charteris-Black 2005 on presidents and other leaders).

\section{Conclusion: aesthetics in epideixis}

Jakobson's work and other studies indicate the importance of verbal aesthetics as a discrete area for exploration, and there is a strong connection between (para)linguistic choices and audience response in the context of political communication.

That we all experience affective reactions to art or music is understood. According to art theorist Funch (2007), subjects confronted with a work of great aesthetic force typically report total and spontaneous engagement of all the senses, a feeling of extreme awe, and abandonment to something larger and ineffable. Sublimity, mediated by the work of art, is quite distinct from the direct experiences of real life events, such as falling in love or being hurt by someone; for one thing it is always ultimately pleasurable, even when the response elicited from the subject is one of fear, revulsion or melancholy. Funch identifies two modes of response in the aesthetic experience - spontaneous and reflective. In everyday life experiences, spontaneous and uncontrolled affective response to a stimulus can be seen to correspond to the Freudian primordial child-like state, but this response tends to be diminished by cultural and cognitive development, to the point where such an event is rare for the socially-functional, reflective adult. Once reflection is activated, the aesthetic experience, however powerful, is categorized and attached to stored memories and other schemata that are likely to mitigate the response and bring it under a socially-acceptable form of control. However, Funch (2007: 13) argues, the reflective mode does not necessarily denote a shift to rational or ordered processing. The accessed memories are themselves emotional rather than concrete or specific - being, as he calls them, "spiritual", and are integral to the individual's "personal integrity", which of course is expressed on the social level. In other words, although the process of aesthetic experience cannot be easily articulated, measured or predicted, its range has a role to play in an individual's personal emotional and charismatic "profile".

Understanding the affective experience of art also helps us comprehend the similar function of epideixis. For Prelli (2006) epideixis has the potential to represent humanity at its honourable, consensual best, via modes of expression that are "higher", less individualistic and more abstract than those found in other areas of political discourse. Surely then, whatever the nature of the individual "spiritual" experience, epideixis is emotionally powerful art precisely because it is crafted as a performative experience to be shared with other participants, and mutual physical proximity intensifies the emotional charge. The aesthetic values 
underlying events like Memorial Day derive from and generate specific sensory associations - verbal, visual, aural and locational - and herein lies their rhetorical function. So in the seemingly simple process of getting audiences to remember, presidents are doing a great deal more.

\section{Notes}

1 Transcripts of all Memorial Day speeches are archived at the University of California Santa Barbara, American Presidency Project: www.ucsb.edu.

2 A transcript of the Gettysburg Address can be found at americanrhetoric.com.

3 Cf. apodeixis - the term with which Aristotle in Rhetoric designates more logical "display" such as the presentation of logical evidence.

4 An example of a far-reaching metaphorical innovation that has become normative would be Churchill's important designation of the division of post-war Europe by an "iron curtain". It is a sad irony that this metaphor has also been realized materially in the Berlin Wall, the Gaza fence and on the US-Mexican border.

\section{References}

Aristotle (1954) The Rhetoric and The Poetics. Translated by W. Rhys Roberts. London: Random House.

Burgess, Theodore C. (1902) Epideictic Literature. Chicago: University of Chicago Press.

Burke, Kenneth (1945) A Grammar of Motives. New York: Prentice Hall

Burke, Kenneth (1966) Language as Symbolic Action. Berkeley, CA: University of California Press. Charteris-Black, Jonathan (2005) Politicians and Rhetoric. London: Palgrave Macmillan.

Chase, J. Richard (1961) "The classical conception of epideictic" Quarterly Journal of Speech 47, 293-300.

Emrich, Cynthia, Holly Brower, Jack Feldman and Howard Garland (2001) "Images in words: presidential rhetoric, charisma and greatness". Administrative Science Quarterly, 46, 527-557.

Fiol, C. Marlene, Drew Harris and Robert House (1999) "Charismatic leadership: strategies for effecting social change". Leadership Quarterly 10, 449-482.

Fisher, Walter (1970) “A motive view of communication”. Quarterly Journal of Speech 56 (2), 131-139.

Fisher, Walter and Stephen O'Leary (1996) “The rhetorician's quest”. In: Salwen, Michael and Don Stacks (2008) An Integrated Approach to Communication Theory and Research. Mahwah, NJ: Erlbaum, 246-260.

Fónagy, Ivan (1963) Die Metaphern in der Phonetik: Ein Beitrag zur Entwicklungsgeschichte des Wissenschaftlichen Denkens. The Hague, NL: Mouton \& Co.

Fónagy, Ivan (1965) "Form and function of poetic language". Diogenes 51. Retrieved from http:// dio.sagepub.com.

Foucault, Michel (1970) The Order of Things. London: Tavistock.

Funch, Bjarne (2007) "A psychological theory of the aesthetic experience". In: Dorfman, Leonid, Colin Martindale and Vladimir Petrov (eds.) Aesthetics and Innovation. Newcastle: Cambridge Scholars Publishing, 3-19.

Goffman, Erving (1959) The Presentation of the Self in Everyday Life. New York: Anchor Doubleday.

Hall, Stuart (1980) "Encoding/Decoding”. In: Hall, Stuart, Dorothy Hobson, Andrew Lowe and Paul Willis (eds.) Culture, Media, Language: Working Papers in Cultural Studies, 1972-79. London: Hutchinson, 507-517. 
House, Robert J. and Boas Shamir (1993) "Toward the integration of transformational, charismatic and visionary theories of leadership". In: Cherners, Martin and Roya Ayman (eds.) Leadership: Perspectives and Research Directions. New York: Academic Press, 81-107.

Jakobson, Roman (1942) Lectures on Sound and Meaning. Cambridge, MA: MIT Press.

Jakobson, Roman and Morris Halle (1956) Fundamentals of Language. The Hague and Paris: Mouton.

Jakobson, Roman (1960) "Introduction to Linguistics and poetics". In: Sebeok, Thomas A. (ed.) Style in Language. Cambridge, MA: MIT Press, 350-377.

Kövecses, Zoltan (2002) Metaphor: A Practical Introduction. Oxford: Oxford University Press.

Lakoff, George and Mark Johnson (1980) Metaphors We Live By. Chicago: Chicago University Press.

Lakoff, George (2004) Don't Think of an Elephant: Know Your Values and Frame the Debate. White River Junction VT: Chelsea Green.

Leech, Geoff (1969) A Linguistic Guide to English Poetry. London: Longman.

Martindale, Colin (1975) Romantic Progression: The Psychology of Literary History. Washington DC: Hemisphere.

McQuarrie, Edward F. and David Mick (1992) "On resonance: a critical pluralistic inquiry into advertising rhetoric", Journal of Consumer Research 19 (3), 180-197.

van Peer, Willie, Frank Hakemulder and Sonia Zyngier (2007) "Lines on feeling: foregrounding, aesthetics and meaning". Language and Literature 16, 197-215.

Perelman, Chaim and Lucie Olbrechts-Tyteca (1969) The New Rhetoric: A Treatise on Argumentation. Notre Dame, Indiana: University of Notre Dame Press.

Prelli, Lawrence J. (2006) (ed.) Rhetorics of Display. Columbia: University of South Carolina Press. Quintilian (1920-22) Institutio Oratoria. Translated by Harold Butler. Loeb Classical Library.

Rollins, Brooke (2005) The ethics of epideictic rhetoric: addressing the problem of presence through Derrida's funeral orations" Rhetoric Society Quarterly, 35 (1), 5-24.

Samuels, Michael L. (1972) Linguistic Evolution. Cambridge: Cambridge University Press. de Saussure, Ferdinand (1977[1916]) Course in General Linguistics. Glasgow: Fontana/Collins.

Simpson, Paul (2004) Stylistics: A Resource Book for Students. London: Routledge.

Slavíčková, Tess (2013) “The rhetoric of remembrance: presidential Memorial Day speeches". Discourse and Society 24 (3), 361-379.

Vico, Giambattista (1968) The New Science. Translated by Thomas Bergin and Max Finch. Ithaca: Cornell University Press.

White, Hayden (1978) Tropics of Discourse: Essays in Cultural Criticism. Baltimore, MD: Johns Hopkins University Press

Wilden, Anthony (1987) The Rules Are No Game: The Strategy of Communication. London: Routledge.

Tess SlavíčKová is lecturer in Communication and Media at the University of New York in Prague. She obtained her PhD in Applied Linguistics under the supervision of Professor Ruth Wodak at Lancaster University. Her areas of interest include multimodal discourse analysis of political speeches and media representation of minorities.

Address: Tess Slavíčková, PhD, Department of Communication and Media, Empire State College/ University of New York in Prague, Legerova 72, 12000 Prague, Czech Republic [email: slavtess@ seznam.cz] 
